No 4069

Studia nad Autorytaryzmem i Totalitaryzmem 43, nr 2

Wrocław 2021

https://doi.org/10.19195/2300-7249.43.2.32

\author{
WITOLD MAŁECKI \\ ORCID: 0000-0002-8819-0317 \\ Uniwersytet Wrocławski \\ witold.malecki@uwr.edu.pl
}

\title{
Prawo gospodarcze w trychotomicznym podziale prawa Wramszapu Samsonowicza Tadewosjana
}

\author{
Słowa kluczowe: prawo gospodarcze, gałąź prawa, system prawa, prawo radzieckie, W.S. Ta- \\ dewosjan. \\ ECONOMIC LAW IN VRAMSHAP SAMSONOVICH TADEVOSYAN'S \\ TRICHOTOMOUS DIVISION OF THE LAW
}

\begin{abstract}
In 1956, the Soviet legal science resumed discussion on the structure of the legal system, in particular - its division into branches. In the years 1938-1956, as a result of rejecting the concept of unified economic law, Soviet science did not use the category of "economic law" at all. The first scholar who in 1956 re-proposed the separation of economic law in the Soviet legal system was Vramshap Samsonovich Tadevosyan. His arguments for the separation of economic law referred to both practical (pragmatic) and theoretical reasons. On the one hand, Tadevosyan pointed out that the separation of economic law would contribute to improving the legal system of national economy management, which would be conducive to the implementation of the sixth five-year plan, adopted at the 20th Congress of the Communist Party of the Soviet Union in 1956. On the other hand, he emphasized that regulating the functioning of the national economy by the provisions of civil law - as has been the case so far - was unacceptable due to the incompatibility of relations within the national economy with the civil law paradigm. Tadevosyan saw economic law as one from among the three branches of the Soviet legal system - the other branches being state law and civil law.
\end{abstract}

Keywords: economic law, branch of law, system of law, Soviet law, V.S. Tadevosyan. 


\section{I}

W historii Związku Radzieckiego rok 1956 był w wielu aspektach przełomowy. Zapoczątkowane w nim zmiany w sferach życia społecznego, politycznego i gospodarczego uwarunkowane były w zasadniczym stopniu konkluzjami XX Zjazdu Komunistycznej Partii Związku Radzieckiego, przeprowadzonego w lutym owego roku. Zjazd ten identyfikuje się jako zdarzenie o fundamentalnym znaczeniu dla „odwilży” postalinowskiej, kojarzonej przede wszystkim ze złagodzeniem represyjnej polityki wobec społeczeństwa. Rok 1956 odznaczył się wszakże doniosłością również dla nauki prawa radzieckiego, w szczególności zaś — dla koncepcji prawa gospodarczego. „Odwilż” 1956 roku doprowadziła do uwolnienia, „odmrożenia” dyskusji nad ukształtowaniem struktury poziomej systemu prawa radzieckiego, a ściślej rzecz ujmując - jego podziału na gałęzie. Przed rokiem 1956 za obowiązujące uznawano stanowisko wypracowane podczas dyskusji przeprowadzonej w latach 1938-1940, w której ważną rolę odegrał prokurator generalny ZSRR A.J. Wyszyński, podkreślający, że właściwie ustrukturyzowany system prawa stanowi „klucz do poznania natury, zasad i właściwości prawa w ogólności oraz każdej ze szczegółowych instytucji prawa"1. W rezultacie tej dyskusji za jedyne kryterium wyróżniania gałęzi prawa uznano przedmiot regulacji, odmawiając podobnego statusu metodzie regulacji ${ }^{2}$. Na podstawie kryterium przedmiotu regulacji Wyszyński wyróżnił katalog dziewięciu gałęzi prawa: państwowego, pracy, kołchozowego, administracyjnego, budżetowo-finansowego, rodzinnego, cywilnego, karnego i sądowego ${ }^{3}$, który na przestrzeni kolejnych lat nie był poddawany zasadniczej krytyce.

Znamiennym ,nieobecnym” w przywołanym katalogu gałęzi prawa było prawo gospodarcze, które przed rokiem 1938 stanowiło przedmiot ożywionych rozważań i analiz w radzieckiej nauce prawa. Za najdonioślejsze wówczas koncepcje prawa gospodarczego należy uznać koncepcję „dwóch sektorów” P.I. Stuczki ${ }^{4}$ z przełomu lat dwudziestych i trzydziestych oraz koncepcję jednolitego prawa gospodarczego L.J. Gincburga i J.B. Paszukanisa ${ }^{5}$, dominującą w latach trzydziestych. Koncepcja jednolitego prawa gospodarczego zakładała objęcie ramami prawa gospodarczego całokształtu prawnej regulacji stosunków o charakterze

${ }^{1}$ A.Â. Vyšinskij, XVIII s"ezd VKP(b) i zadači nauki socialističeskogo prava, ,Sovetskoe gosudarstvo i prawo" 1939, nr 3, s. 23. Przeł. W.M.

${ }^{2}$ I.V. Pavlov, O sisteme sovetskogo socialističeskogo prava, „Sovetskoe gosudarstvo i prawo" 1958 , nr 11, s. 6.

3 A.Â. Vyšinskij, op. cit., s. 39.

${ }^{4}$ P.I. Stučka, Kurs sovetskogo graždanskogo prava, t. 3. Osobennaâ čast' graždanskogo prava, Moskwa-Leningrad 1931, s. 5-6, 9. Zob. też W. Małecki, Prawo gospodarczo-administracyjne w koncepcji „, dwóch sektorów” Piotra Iwanowicza Stuczki, „Studia nad Autorytaryzmem i Totalitaryzmem" 42, 2020, nr 2, s. 101-117.

5 Kurs sovetskogo hozâjstvennogo prava, t. 1, red. E.B. Pašukanis, L.Â. Gincburg, Moskwa 1935, passim. 
majątkowym, co sprawiło, że ukształtowane w ten sposób prawo gospodarcze „wchłonęło" całość unormowań dotychczas zaliczanych do prawa cywilnego ${ }^{6}$. Koncepcja jednolitego prawa gospodarczego została odrzucona u schyłku lat trzydziestych, przede wszystkim za sprawą stanowiska Wyszyńskiego, według którego koncepcja ta, przeformułowując tradycyjne konstrukcje cywilnoprawne zgodnie z potrzebami regulacji funkcjonowania gospodarki, doprowadziła do „całkowitego niezrozumienia i ignorowania żywych ludzi z ich interesami, prawami, z ich wolą, życzeniami i dążeniami" 7 . Pominięcie prawa gospodarczego w autorytatywnie sformułowanym, de facto „wiążącym”, katalogu gałęzi prawa sprawiło, że — jak zaznaczał W.K. Mamutow - w 1938 roku rozpoczął się w ZSRR okres ,zakazu nauki prawa gospodarczego" 8 .

Dyskusja nad strukturą poziomą systemu prawa radzieckiego, jak wspomniano, została podjęta na nowo w 1956 roku i toczyła się głównie na łamach czasopisma „Radzieckie Państwo i Prawo” („Sovetskoe gosudarstvo i prawo”), w którym publikowano artykuły poświęcone systemowi prawa i jego podziałowi na gałęzie autorstwa wielu czołowych przedstawicieli nauki prawa radzieckiego. W dyskusji tej często odnoszono się do zasadności wyróżniania wśród gałęzi prawa także prawa gospodarczego ${ }^{9}$ - niekiedy wręcz rozważania poświęcone prawu gospodarczemu stawały się podstawą i punktem wyjścia do ogólnych rozważań o podziale prawa na gałęzie. Jako bezpośrednią przesłankę konieczności podjęcia refleksji nad wyróżnieniem prawa gospodarczego wskazywano często przyjęcie na XX Zjeździe KPZR szóstego pięcioletniego planu rozwoju gospodarki narodowej ZSRR, którego realizacja wymagała istnienia efektywnych ram prawnych zarządzania gospodarką — podczas obrad Zjazdu premier ZSRR N.A. Bułganin wskazał na konieczność udoskonalenia i uszczegółowienia systemu zarządzania gospodarką narodową, posługując się Leninowskim zawołaniem „Więcej konkretów!" (Bol'še konkretnosti!) $)^{10}$.

Wśród uczonych, którzy w dyskusji na łamach „Radzieckiego Państwa i Prawa" postulowali wyodrębnienie prawa gospodarczego w systemie prawa radzieckiego, za pioniera należy uznać W.S. Tadewosjana ${ }^{11}$ — to jego artykuł pt. „Niektóre problemy systemu prawa radzieckiego” był pierwszym tekstem

${ }^{6}$ O.S. Ioffe, Izbrannye trudy po graždanskomu pravu. Iz istorii civilističeskoj mysli. Graždanskoe pravootnošenie. Kritika teorii ,, hozâjstvennogo prava”, Moskwa 2000, s. 213-214.

7 Za: L.Â. Gincburg, K voprosu o hozâjstvennom prave, „Sovetskoe gosudarstvo i prawo" 1956, nr 10, s. 87. Przeł. W.M.

8 V.K. Mamutov, Hozâjstvennoe prawo, Kijów 2002, s. 7.

${ }^{9}$ Zob. W. Małecki, Dyskusja nad koncepcja prawa gospodarczego w nauce radzieckiej w latach 1956-1958, „Krakowskie Studia z Historii Państwa i Prawa” 9, 2016, z. 3, s. 361-376.

10 N.A. Bulganin, Direktivy XX s"ezda KPSS po šestomu pâtiletnemu planu razvitiâ narodnogo hozâjstva SSSR, [w:] XX s"ezd Kommunističeskoj Partii Sovetskogo Soûza, 14-25 fevralâ 1956 goda. Stenografičeskij otčet, t. 2, Moskwa 1956, s. 13.

11 O.V. Romanovskaâ, Pravo i èkonomika v Rossijskoj Federacii (ot hozâjstvennogo prava $k$ megaotrasli), „Nauka. Obŝestvo. Gosudarstvo” 8, 2020, nr 4, s. 36. 
wskazującym na konieczność wyróżnienia prawa gospodarczego. Tadewosjan postrzegał prawo gospodarcze jako jedną z trzech podstawowych gałęzi tworzących system prawa radzieckiego — do gałęzi tych zaliczył także prawo państwowe i cywilne ${ }^{12}$. W niniejszym artykule przedstawiony zostanie zarys stanowiska Tadewosjana w kwestii uzasadnienia i sposobu wyodrębnienia prawa gospodarczego w trychotomicznym podziale prawa.

\section{II}

Wramszapu Samsonowicz Tadewosjan urodził się w 1900 roku w miejscowości Wierchnie Akulisy na terytorium dzisiejszego Azerbejdżanu. Był z pochodzenia Ormianinem. Początkowe lata jego działalności prawniczej wiązały się z pracą w instytucjach państwowych - był zatrudniony w Sądzie Najwyższym Rosyjskiej Federacyjnej Socjalistycznej Republiki Radzieckiej, Ludowym Komisariacie Sprawiedliwości RFSRR, Prokuraturze ZSRR, w latach 1947-1949 zajmował stanowisko Prokuratora Armeńskiej Socjalistycznej Republiki Radzieckiej. W 1946 roku brał udział w pracach Międzynarodowego Trybunału Wojskowego dla Dalekiego Wschodu jako asystent oskarżyciela delegowanego z ramienia ZSRR. W późniejszych latach życia Tadewosjan koncentrował się na działalności naukowej — w 1948 roku uzyskał stopień kandydata nauk prawnych na podstawie dysertacji „Rewizja orzeczeń sądowych w trybie nadzoru”, a w roku 1958 został doktorem nauk prawnych, broniąc pracy „Nadzór prokuratorski w ZSRR". Jego zainteresowania naukowe odznaczały się szerokim zakresem - publikował prace z zakresu prawa cywilnego, rodzinnego, karnego, procesowego i innych dziedzin. W.S. Tadewosjan zmarł w 1979 roku $^{13}$.

Zgodnie z duchem czasu przypadającego po XX Zjeździe KPZR, Tadewosjan punktem wyjścia dla swoich rozważań o statusie prawa gospodarczego uczynił znaczenie wyróżnienia tej gałęzi prawa dla rozwoju gospodarki narodowej. Wprost stwierdził bowiem, że ,prace naukowe poświęcone problemom prawa gospodarczego powinny być oceniane z perspektywy ich znaczenia dla praktyki organizacji gospodarki, ich pożyteczności dla gospodarki narodowej”, przy czym „dlatego konieczne jest zaprzestanie niedoceniania teoretycznych problemów radzieckiego prawa gospodarczego", albowiem „,należy rozwijać radzieckie prawo gospodarcze, jako równoprawną i ważną gałąź prawa w systemie nauki prawa radzieckiego"14. Tadewosjan nawiązał także do słów N.A. Bułganina wygłoszonych podczas obrad Zjazdu, a także do przyjętego na Zjeździe szóstego planu pięcioletniego,

12 V.S. Tadevosân, Nekotorye voprosy sistemy sovetskogo prava, ,Sovetskoe gosudarstvo i prawo" 1956, nr 8, s. 105.

13120 let so dnâ roždeniâ doktora ûridičeskih nauk, professora Vramšapu Samsonoviča Tadevosâna, „Vestnik graždanskogo processa” 2020, nr 5, s. 306-307.

14 V.S. Tadevosân, Nekotorye voprosy..., s. 101. Przeł. W.M. 
który miał wymagać „skrętu nauki prawa cywilnego i gospodarczego w kierunku potrzeb rozwoju gospodarki narodowej ZSRR"15. Zwolennikom dotychczas przyjmowanego w nauce podziału prawa na gałęzie, nieuwzględniającego prawa gospodarczego, zarzucał brak zrozumienia mechanizmów funkcjonowania gospodarki, jako że „większość badaczy teorii nie miało silnych związków z praktyką pracy organizacji gospodarczych"16. Wyróżnienie prawa gospodarczego miało służyć intensyfikacji badań nad prawnym ujęciem zasadniczych dla funkcjonowania gospodarki zagadnień takich jak między innymi rachunek ekonomiczny (chozrascziot), dyscyplina umowna czy status dyrektorów przedsiębiorstw były to zagadnienia, które powinny stać się przedmiotem wspólnych analiz podejmowanych przez prawników-teoretyków i prawników-praktyków ${ }^{17}$.

Podkreślając praktyczną doniosłość wyodrębnienia prawa gospodarczego, Tadewosjan uzasadniał wyróżnienie tej gałęzi prawa również w perspektywie teoretycznej. Jego zasadnicza uwaga koncentrowała się tu wokół kwestii odseparowania prawa gospodarczego od prawa cywilnego, w ramach którego (dotychczas) regulowane były stosunki prawne kształtujące się w systemie gospodarki narodowej. Problem normowania funkcjonowania gospodarki narodowej przepisami prawa cywilnego stanowił przedmiot kontrowersji w radzieckiej nauce prawa od początków jej istnienia. Kontrowersje te uwidoczniły się szczególnie wyraźnie w związku z przyjęciem w 1922 roku kodeksu cywilnego RFSRR. Kodeks ten, obejmujący regulacją także stosunki kształtujące się wewnątrz państwowego sektora gospodarki, został poddany krytyce przez uczonych skupionych wokół czasopisma „Prawo i Życie” („Pravo i žizn'”), według których miał on hamować dynamikę rewolucji poprzez sprzyjanie powrotowi burżuazyjnego porządku prawnego i gospodarczego ${ }^{18}$. Dla wielu uczonych radzieckich bardzo wątpliwe było normowanie funkcjonowania socjalistycznych organizacji gospodarczych — państwowego sektora gospodarczego - prawem cywilnym, jako gałęzią o proweniencji burżuazyjnej, opierającej się na paradygmacie regulacji stosunków między podmiotami prywatnymi. W 1940 roku M.M. Agarkow zaznaczał, że termin „prawo cywilne” (w języku rosyjskim graždanskoe prawo — dosłownie „prawo obywatelskie”) „ma czysto umowne znaczenie, już dawno utracił swój pierwotny sens". Proponował w związku z tym wyróżnienie prawa cywilnego gospodarki socjalistycznej i prawa cywilnego jednostkowego obywatela ${ }^{19}$.

W nawiązaniu do powyższych kontrowersji W.S. Tadewosjan negatywnie odnosił się do ujmowania $\mathrm{w}$ ramach prawa cywilnego wszystkich stosunków majątkowych, w tym także stosunków w państwowym sektorze gospodarczym.

15 Ibidem, s. 99, 101. Przeł. W.M.

16 Ibidem, s. 100.

17 Ibidem, s. 101.

18 L.Â. Gincburg, op. cit., s. 85.

19 M.M. Agarkov, Predmet $i$ sistema sovetskogo graždanskogo prava, ,Sovetskoe gosudarstvo i prawo" 1940, nr 8-9, s. 70. 
Wskazywał, że charakter stosunków majątkowych między obywatelami i stosunków majątkowych w państwowym sektorze gospodarczym jest fundamentalnie odmienny. Odmienności te koncentrowały się na dwóch płaszczyznach. Po pierwsze, o ile stosunki między obywatelami nawiązywały się w rezultacie autonomicznych decyzji obywateli, o tyle stosunki w państwowym sektorze gospodarczym kształtowały się wskutek centralnego planowania. Po drugie, stosunki majątkowe między obywatelami odnosiły się do ich własności osobistej, podczas gdy stosunki w państwowym sektorze gospodarczym dotyczyły uspołecznionej własności środków produkcji. Regulowanie funkcjonowania gospodarki prawem cywilnym (to jest prawem „stworzonym przez burżuazję dla regulowania prywatnych stosunków własnościowych") Tadewosjan uważał za naturalne w państwach burżuazyjnych, w których własność środków produkcji przysługuje podmiotom prywatnym, jednak za zupełnie nietrafne w państwie socjalistycznym, gdzie prywatna własność środków produkcji nie istnieje ${ }^{20}$. „Majątkowość” obu wskazanych kategorii stosunków majątkowych Tadewosjan uznawał za zdecydowanie zbyt wątły wspólny mianownik, by stosunki te mogły być regulowane w ramach jednej gałęzi - prawa cywilnego. Wskazał przeto na konieczność wyodrębnienia prawa gospodarczego, będącego gałęzią prawa obejmującą ,zbiór norm prawnych regulujących działalność przedsiębiorstw, organizacji, osób odpowiedzialnych i obywateli w dziedzinie zarządzania i rozwoju socjalistycznej gospodarki narodowej"21.

\section{III}

Tadewosjan postrzegał prawo gospodarcze jako jedną z trzech gałęzi tworzących system prawa radzieckiego. Jakkolwiek zasadniczo uznawał, że właściwym kryterium podziału prawa na gałęzie jest przedmiot regulacji ${ }^{22}$, to jednak skonstruowany przez niego trychotomiczny podział prawa zasadzał się w istocie na odzwierciedleniu poszczególnych ,zadań stojących przed prawem radzieckim i socjalistyczną praworządnością, ponieważ normy prawa są ustanawiane w celach realizacji tych zadań" 23 . Prawo państwowe miało służyć ochronie i utrwaleniu radzieckiego ustroju państwowego, prawo gospodarcze koncentrowało się wokół ochrony i utrwalenia socjalistycznego systemu gospodarki i własności socjalistycznej, prawo cywilne było nakierowane na ochronę praw obywateli ${ }^{24}$. Każda z tych gałęzi miała obejmować węższe podgałęzie. Wewnątrz prawa państwowego sytuowały się prawo konstytucyjne, administracyjne, finansowe, karne, o ustroju sądów, proceduralne i o nadzorze prokuratorskim. Do prawa gospodarczego

\footnotetext{
20 V.S. Tadevosân, Nekotorye voprosy..., s. 102-103.

21 Ibidem, s. 103. Przeł. W.M.

22 Ibidem, s. 102.

23 Ibidem, s. 104. Przeł. W.M.

24 Ibidem, s. 105.
} 
zaliczone zostały prawo przemysłowe, transportowe, rolne, spółdzielcze, handlowe, komunalno-mieszkaniowe i bankowo-kredytowe. Prawo cywilne miało obejmować prawo rodzinne, pracy, emerytalne, własności osobistej, spadkowe, autorskie, wynalazcze, mieszkaniowe i obligacyjne ${ }^{25}$. Tadewosjan podkreślał, że ukształtowane zgodnie z jego koncepcją prawo cywilne zmieni swój charakter - jego osią przewodnią nie będzie już bowiem, jak dotychczas, regulacja stosunków majątkowych, lecz normowanie praw i obowiązków obywateli. Co z tym związane, postulował on przyjęcie kodeksu cywilnego ZSRR, mającego stać się powszechnie dostępnym dla ludności aktem prawnym, z którego „każdy obywatel ZSRR mógłby dowiedzieć się o swoich prawach i obowiązkach" w różnych dziedzinach życia ${ }^{26}$. Inaczej niż w przypadku prawa cywilnego, w odniesieniu do prawa gospodarczego Tadewosjan nie uważał za zasadne stworzenia kodeksu, kompleksowo ujmującego materię normatywną sytuowaną w ramach tej gałęzi prawa. Wskazywał bowiem, że z uwagi na różnorodność i specyfikę poszczególnych gałęzi gospodarki narodowej właściwe będzie ustanawianie odrębnych aktów prawnych dotyczących określonych gałęzi gospodarki ${ }^{27}$.

Przyjęte przez W.S. Tadewosjana kryterium podziału prawa na gałęzie stało się głównym przedmiotem krytyki formułowanej w literaturze w odniesieniu do przedstawionej koncepcji. Wśród autorów, którzy szczególnie negatywnie odnosili się do stanowiska W.S. Tadewosjana, warto odwołać się do czechosłowackiego uczonego W. Knappa, czołowych radzieckich cywilistów M.D. Szargorodskiego i O.S. Joffego, a także znamienitego administratywisty G.I. Pietrowa. Zgodnie wskazywali oni, że wyróżnienie gałęzi prawa przez Tadewosjana nastąpiło na podstawie niejednakowych kryteriów. Prawo cywilne zostało wyodrębnione na podstawie kryterium podmiotowego (jako prawo normujące status prawny obywatela $^{28}$, prawo gospodarcze wydzielono według regulowanej w jego ramach dziedziny działalności - gospodarczej ${ }^{29}$, podczas gdy dla prawa państwowego próżno szukać pewnego jednolitego kryterium wyodrębnienia ${ }^{30}$. Jako główny skutek powyższej okoliczności postrzegano przede wszystkim daleko posunięty brak precyzji dokonanego przez Tadewosjana podziału prawa na gałęzie. W. Knapp wskazał na trudności związane z określeniem gałęziowoprawnej przynależności instytucji prawnych, które znajdują zastosowanie zarówno w gospodarce państwowej, jak i stosunkach między obywatelami. Przykładowo, naprawienie szkody — jakkolwiek może występować w relacjach między przedsiębiorstwami

25 Ibidem, s. 105, 107.

26 Ibidem, s. 105-106. Przeł. W.M.

27 Ibidem, s. 107.

28 V. Knapp, Po povodu diskussii o sisteme prava, ,Sovetskoe gosudarstvo i prawo" 1957, nr 5, s. 117.

29 M.D. Šargorodskij, O.S. Ioffe, O sisteme sovetskogo prava, „Sovetskoe gosudarstvo i prawo" 1957, nr 6, s. 106.

30 G.I. Petrov, Suŝnost' sovetskogo administrativnogo prava, Leningrad 1959, s. 100. 
państwowymi i między obywatelami — jest instytucją o spójnej tożsamości i nie powinno być „rozłączane” między prawo gospodarcze i prawo cywilne ${ }^{31}$. G.I. Pietrow oraz M.D. Szargorodski i O.S. Joffe akcentowali także brak wewnętrznej integralności prawa gospodarczego w kształcie wyznaczonym przez Tadewosjana. Stosunki kształtujące się w poszczególnych gałęziach gospodarki narodowej, regulowane prawem gospodarczym, przywołani autorzy uznawali za różnorodne do tego stopnia, że niemożliwe byłoby stworzenie pewnej „części ogólnej” prawa gospodarczego czy też ukształtowanie się nauki prawa gospodarczego byłaby ona bowiem pozbawiona problemów badawczych wspólnych dla regulacji wszystkich dziedzin gospodarki ${ }^{32}$.

\section{IV}

Ogólna refleksja nad zarysowanym powyżej stanowiskiem Tadewosjana w kwestii wyodrębnienia prawa gospodarczego jako jednej z gałęzi w ramach trychotomicznego podziału prawa wymaga rozłączenia dwóch substratów (tez) tego stanowiska - po pierwsze, samego wyodrębnienia prawa gospodarczego w systemie prawa; po drugie, postrzegania go jako jednej z trzech gałęzi prawa tworzących system prawa. Pierwsza teza, zakładająca przydanie prawu gospodarczemu statusu odrębnej gałęzi prawa, oddzielnej od prawa cywilnego, zyskała niejaką popularność w nauce radzieckiej i legła u podstaw tak zwanej powojennej koncepcji prawa gospodarczego, której przedstawicielami byli między innymi W.W. Łaptiew, W.K. Mamutow oraz G.M. Swierdłow ${ }^{33}$. Warto zaznaczyć, że również przeciwnicy koncepcji prawa gospodarczego przyznawali, że istnieją pewne okoliczności mogące przemawiać za oddzieleniem prawa gospodarczego od prawa cywilnego. Przykładowo, W. Knapp zaznaczał, że trudno nie zgodzić się z Tadewosjanem co do fundamentalnych odmienności różniących stosunki cywilnoprawne między obywatelami i stosunki cywilnoprawne między państwowymi organizacjami gospodarczymi — nie postrzegał ich jednak za doniosłe na tyle, by mogły uchybić integralności prawa cywilnego ${ }^{34}$. Druga teza Tadewosjana, wskazująca na zasadność wyróżnienia w systemie prawa trzech gałęzi — państwowego, gospodarczego i cywilnego - nie zyskała uznania nawet wśród zwolenników koncepcji prawa gospodarczego. Nie sposób nie podzielić bowiem argumentacji

31 V. Knapp, op. cit., s. 118.

32 M.D. Šargorodskij, O.S. Ioffe, op. cit., s. 106; G.I. Petrov, op. cit., s. 100. Warto wszakże zaznaczyć, że w odpowiedzi na powyższy zarzut Tadewosjan w artykule opublikowanym w 1959 roku przedstawił koncepcję wewnętrznej struktury prawa gospodarczego, obejmującej część ogólną i część szczegółową — zob. V.S. Tadevosân, Suŝnost' sovetskogo hozâjstvennogo prava i predstoâsâa kodifikaciâ graždanskogo zakonodatel'stva SSSR, „Sovetskoe gosudarstvo i prawo” 1959, nr 6, s. 61.

33 Zob. E.B. Bragina, Rossijskoe predprinimatel'skoe pravo, Nowosybirsk 2011, s. 6.

34 V. Knapp, op. cit., s. 120. 
krytyków tej tezy, podkreślających przeprowadzenie trychotomicznego podziału prawa bez zachowania jednolitego kryterium podziału. Niemniej stanowisko Tadewosjana co do statusu prawa gospodarczego z pewnością zasługuje na dostrzeżenie i utrwalenie jako głos, który w 1956 roku na nowo wprowadził problem prawa gospodarczego do radzieckiego dyskursu prawniczego.

\section{Bibliografia}

120 let so dnâ roždeniâ doktora ûridičeskih nauk, professora Vramšapu Samsonoviča Tadevosâna, „Vestnik graždanskogo processa” 2020, nr 5.

Agarkov M.M., Predmet i sistema sovetskogo graždanskogo prava, „Sovetskoe gosudarstvo i prawo" 1940, nr 8-9.

Bragina E.B., Rossijskoe predprinimatel'skoe pravo, Nowosybirsk 2011.

Bulganin N.A., Direktivy XX s"ezda KPSS po šestomu pâtiletnemu planu razvitiâ narodnogo hozâjstva SSSR, [w:] XX s"ezd Kommunističeskoj Partii Sovetskogo Soûza, 14-25 fevralâ 1956 goda. Stenografičeskij otčet, t. 2, Moskwa 1956.

Gincburg L.Â., K voprosu o hozâjstvennom prave, „Sovetskoe gosudarstvo i prawo” 1956, nr 10.

Ioffe O.S., Izbrannye trudy po graždanskomu pravu. Iz istorii civilističeskoj mysli. Graždanskoe pravootnošenie. Kritika teorii , hozâjstvennogo prava”, Moskwa 2000.

Knapp V., Po povodu diskussii o sisteme prava, „Sovetskoe gosudarstvo i prawo” 1957, nr 5.

Kurs sovetskogo hozâjstvennogo prava, t. 1, red. E.B. Pašukanis, L.Â. Gincburg, Moskwa 1935.

Małecki W., Dyskusja nad koncepcja prawa gospodarczego w nauce radzieckiej w latach 19561958, „Krakowskie Studia z Historii Państwa i Prawa” 9, 2016, z. 3.

Małecki W., Prawo gospodarczo-administracyjne w koncepcji „,dwóch sektorów” Piotra Iwanowicza Stuczki, „Studia nad Autorytaryzmem i Totalitaryzmem” 42, 2020, nr 2.

Mamutov V.K., Hozâjstvennoe prawo, Kijów 2002.

Pavlov I.V., O sisteme sovetskogo socialističeskogo prava, „Sovetskoe gosudarstvo i prawo” 1958, nr 11.

Petrov G.I., Suŝnost' sovetskogo administrativnogo prava, Leningrad 1959.

Romanovskaâ O.V., Pravo i èkonomika v Rossijskoj Federacii (ot hozâjstvennogo prava k megaotrasli), „Nauka. Obŝestvo. Gosudarstvo” 8, 2020, nr 4.

Šargorodskij M.D., Ioffe O.S., O sisteme sovetskogo prava, „Sovetskoe gosudarstvo i prawo” 1957, nr 6.

Stučka P.I., Kurs sovetskogo graždanskogo prava, t. 3. Osobennaâ čast' graždanskogo prava, Moskwa-Leningrad 1931.

Tadevosân V.S., Nekotorye voprosy sistemy sovetskogo prava, „Sovetskoe gosudarstvo i prawo” 1956, $\mathrm{nr} 8$.

Tadevosân V.S., Suŝnost' sovetskogo hozâjstvennogo prava i predstoâsâa kodifikaciâ graždanskogo zakonodatel'stva SSSR, „Sovetskoe gosudarstvo i prawo” 1959, $\mathrm{nr} 6$.

Vyšinskij A.Â., XVIII s"ezd VKP(b) i zadači nauki socialističeskogo prava, „Sovetskoe gosudarstvo i prawo" $1939, \mathrm{nr} 3$. 